\title{
Phenotypic and genotypic evaluation of antibiotic resistance and molecular characterization of Streptococcus species isolated from hospital cockroaches
}

Mohammad Chehelgerdi

Islamic Azad University Shahrekord Branch

Reza Ranjbar ( $\sim$ pbioshk@gmail.com )

Baqiyatallah University of Medical Sciences

\section{Research Article}

Keywords: Streptococcus species, Virulence factors, Antibiotic resistance, Cockroaches, Hospital

Posted Date: April 24th, 2020

DOI: https://doi.org/10.21203/rs.3.rs-23316/v1

License: (a) (1) This work is licensed under a Creative Commons Attribution 4.0 International License. Read Full License 


\section{Abstract \\ Background}

The present investigation aimed to assess the antibiotic resistance properties and distribution of virulence factors in the Streptococcus spp. isolated from hospital cockroaches.

\section{Methods}

Six-hundred and sixty cockroach samples were collected. Cockroaches were vigorously washed with normal saline, and the achieved saline was used for bacterial culture. Isolated Streptococcus spp. were subjected to disk diffusion as well as PCR amplification of virulence factors and antibiotic resistance genes.

\section{Results}

Prevalence of S. pyogenes, S. agalactiae and S. pneumonia was $4.82 \%, 1.66 \%$ and $6.96 \%$, respectively. The highest prevalence of $S$. pyogenes, S. agalactiae and S. pneumonia were found in oriental (5.71\%), oriental (2.85\%) and American (7.71\%) cockroaches, respectively. Cfb (53.93\%), cyl (52.8\%), scaa $(51.68 \%)$ and $g$ Ina $(50.56 \%)$ were the most commonly detected streptococcal virulence factors. $P b p 2 b$ (71.91\%), pbp2 $\times(58.42 \%)$, mefA $(46.06 \%), \operatorname{ermB}(46.06 \%)$ and tetM $(46.06 \%)$ were the most commonly detected antibiotic resistance genes. Streptococcal spp. exhibited the highest prevalence of resistance against tetracycline (80.89\%), trimethoprim (65.16\%), and penicillin $(56.17 \%)$.

\section{Conclusion}

To the best of our knowledge, this is the first prevalence report of virulence factors and antibiotic resistance genes in the Streptococcal spp. isolated from American, German and oriental hospital cockroaches. Findings recommended a certain role for cockroaches in the transmission of nosocomial infections and particularly those caused by virulent and resistant Streptococcus spp. in the hospital environment.

\section{Background}

Cockroaches are considered among the most common pests in numerous homes and public places such as hospitals, hotels, bughouses, boarding schools, barracks, kindergartens and dorms. Pest cockroaches are in close contact with human [1].Originally, they are tropical; however, in the temperate zones, most species live in parts of houses and other places where moisture, warmth, and food are adequate. Among over 3,500 recognized species, only few ones are important to human, including Blattella germanica 
(German cockroach), Periplaneta americana (American cockroach) and Blatta orientalis (Oriental cockroach) [2-6].

Cockroaches easily move from buildings, gardens, drains, sewers and latrines to human habitations. Since they feed on human food and feces, they can spread several types of pathogenic microorganisms. Likewise, several epidemiological investigations indicated that cockroaches were one of the main sources of different types of dangerous bacteria such as Shigella dysenteriae, Salmonella typhi, Streptococcus species (spp.), Staphylococcus aureus, Escherichia coli, and Pseudomonas aeruginosa [2-6].

Streptococci are anaerobic gram-positive cocci forming a heterogeneous group with more than 30 different species. Some species such as $S$. pneumoniae, S. pyogenes (Lancefield Group A) and $S$. agalactiae (Lancefield Group B) are substantial human pathogens [7-12]. S. pneumoniae is recognized as one of the main causes of pneumonia, septic arthritis, acute sinusitis, endocarditis, pericarditis, peritonitis, meningitis and septicaemia $[9,11,12]$. $S$. pyogenes causes serious infections in cases where it becomes invasive (sepsis, necrotizing fasciitis, etc.), infections that are not immunological complications and serious (tonsillitis, superficial skin infections) $[7,9,11]$. Lastly, $S$. agalactiae is the most common cause of neonatal sepsis as well as animal mastitis $[9,10]$.

Streptococcus spp. are mostly resistant against a number of antibiotics. In this regard, documented data indicated that Streptococcus spp. isolated from various clinical infections harbored the high prevalence of resistance against different antibiotics such as aminoglycosides, ampicillin, cephalothin, fluoroquinolone, sulfonamides, tetracyclines, trimethoprim, gentamicin and chloramphenicol $[13,14]$. Studies into molecular epidemiological demonstrated that presence of certain antibiotic resistance genes, including those encoding resistance against penicllins ( $\mathrm{pbp}$ (penicillin binding protein)), tetracyclines (tetK, tetM, tetO and tet $L$ ), macrolides (erm ((erythromycin ribosome methylase) and mef (macrolide efflux)), streptogramins A and B ( $r p / V)$ (L22 and L4 ribosomal protein gene) and lytA (autolysin-encoding gene) are the most important reason for the occurrence of antibiotic resistance in these bacteria $[13,15]$.

Streptococcus spp. isolated from different types of clinical samples harbored the high prevalence of certain virulence factors such as bac (encode for $\beta$-antigen), $c y l$ (encode for $\beta$-hemolysin), $g \ln A$ (encode for glutamine synthetase), $c f b$ (encode for the Christie-Atkins-Munch-Peterson (CAMP) factor), hylB (encode for hyaluronidase), $s c a A$ (encode for aggregation factor), $b c a$ (encode for a-antigen), $s c p B$ (C5a peptidase) and $I m b$ (laminin binding protein) $[16,17]$. Presence of these virulence factors contributes to high pathogenicity of Streptococcus spp. [16, 17].

According to the high presence of cockroaches in the hospital environment as well as their significant importance as risk factors for maintenance and transmission of pathogenic bacteria, the present investigation was conducted to study the prevalence rate, distribution of virulence factors and antimicrobial resistance properties of S. pneumoniae, S. pyogenes and S. agalactiae strains in German, American and Oriental cockroaches of Iranian hospitals. 


\section{Results}

Table 2 presents the total distribution of Streptococcus spp. isolated from different types of hospital cockroaches. Prevalence of $S$. pyogenes, $S$. agalactiae and S. pneumonia strains among all the studied samples was $4.82 \%, 1.66 \%$ and $6.96 \%$, respectively. The highest prevalence of $S$. pyogenes, $S$. agalactiae and S. pneumonia strains was found in oriental cockroaches (5.71\%), oriental cockroaches $(2.85 \%)$ and American cockroaches $(7.71 \%)$, respectively. Statistical significant difference was found between types of cockroaches and prevalence of Streptococcus spp. $(P<0.05)$.

Table 3 shows the distribution of streptococcal putative virulence factors in different types of studied cockroaches. We found that $c f b(53.93 \%), c y l(52.8 \%)$, scaa (51.68\%) and glna (50.56\%) were the most commonly detected streptococcal virulence factors. The highest prevalence of Streptococcal spp. was found in German cockroaches. Statistical significant difference was found between types of cockroaches and prevalence of virulence factors $(P<0.05)$.

Table 4 depicts the distribution of penicillin, macrolides, tetracyclines and streptogramins antibiotic resistance genes in the Streptococcus spp. isolated from different types of hospital cockroaches. We found that $p b p 2 b(71.91 \%), p b p 2 \times(58.42 \%)$, mefA $(46.06 \%), \operatorname{ermB}(46.06 \%)$ and tetM $(46.06 \%)$ were the most commonly detected antibiotic resistance genes in the Streptococcal spp. isolated from different types of hospital cockroaches. TetO (6.74\%), DF-L22 (21.34\%) and DF-L4 (24.71\%) had the lowest prevalence in the studied antibiotic resistance genes. Statistical significant difference was found between types of cockroaches and prevalence of antibiotic resistance genes $(P<0.05)$.

Table 5 presents the antibiotic resistance pattern of the Streptococcus spp. isolated from different types of hospital cockroaches. Streptococcal spp. harbored the highest prevalence of resistance against tetracycline (80.89\%), trimethoprim (65.16\%), and penicillin $(56.17 \%)$, while harbored the lowest against chloramphenicol (3.37\%), ciprofloxacin (19.10\%) and nitrofurantoin (29.21\%). S. pyogenes strains harbored the highest prevalence of resistance against tetracycline (84.37\%), penicillin (81.25\%), enrofloxacin (56.25\%) and erythromycin (53.12\%). S. agalactiae strains harbored the highest prevalence of resistance against trimethoprim $(72.72 \%)$, tetracycline $(72.72 \%)$, penicillin $(63.63 \%)$ and erythromycin (63.63\%). S. pneumoniae strains harbored the highest prevalence of resistance against tetracycline (80.43\%), trimethoprim (73.91\%), and lincomycin (50\%).

\section{Discussion}

Medically, cockroaches are much more important than generally realized as they have been demonstrated to harbor some pathogenic and non-pathogenic microorganisms. Since various workers have reported the isolation of various human pathogens from these insects, cockroaches are known vectors of human enteropathogens. Their filthy and nocturnal habits cause them to be ideal carriers for transmitting 
numerous pathogenic microorganisms. Klebsiella spp., E. coli, P. aeruginosa, Streptococcus spp. and some other potential pathogens have been isolated from cockroaches gathered from hospitals [3-6].

The present investigation was conducted to assess the prevalence rate, antibiotic resistance pattern and genotyping evaluation of antibiotic resistance and virulence factor of the Streptococcus spp. isolated from American, German, Oriental and other species of hospital cockroaches. We found that $S$. pneumoniae had the highest prevalence among the studied cockroaches $(6.96 \%)$. Oriental cockroaches had the highest prevalence of $S$. pyogenes $(5.71 \%)$ and $S$. agalactiae $(2.85 \%)$, while German cockroaches had the highest prevalence of $S$. pneumoniae (6.83\%). Presence of hospital cockroaches in different parts of hospitals, and sewage system caused high prevalence of Streptococcus spp. Although American cockroaches harbored considerable prevalence of bacteria, this species was more often gathered in kitchens, restaurants and supply rooms. In the hospital environment, this distribution, as a vector for nosocomial infections, may reduce its potential. German cockroaches can be a more significant potential vector for nosocomial infections, as they were more commonly found in nursing stations, outpatient rooms, registration rooms, wards, medical record storage rooms as well as drug storage rooms. Various studies have been carried out in this field. For example, Fotedar et al. (1991) [18] indicated that one hundred and fifty-eight out of $159(99-4 \%)$ cockroaches gathered from hospital (test) and 113 out of $120(94-2 \%)$ cockroaches gathered from residential areas (control) carried medically significant microorganisms. They indicated that $10-20 \%$ of cockroaches harbored Streptococcus spp.. Kassiri et al. (2014) [19] disclosed that culturing outer surface wash of cockroaches resulted in the isolation of Klebsiella, Pseudomonas, E. coli, Staphylococcus, Proteus and Streptococcus. The main common bacteria were Klebsiella (35\%) and Pseudomonas (30\%). Elgderi et al. (2006) [20] indicated that 27 and 25 species of potential pathogen were isolated from the hospital and household cockroaches, respectively, with Klebsiella, Enterobacter, Serratia and Streptococcus being predominant. Salehzadeh et al. (2007) [21] demonstrated that 130 out of 133 (98\%) German cockroaches had contamination with high bacterial load (more than $1 \times 10^{3}$ ). Enterobacter (22.60\%), Klebsiela (21\%), Enterococcus $(17.30 \%)$, Staphylococcus (16.50\%), E. coli and Streptococcus (8.3\%), Pseudomonas (3\%), as well as Shigella, Haemophilus and group A ß-hemolytic Streptococcus (less than 1\%) were the most commonly detected bacteria. Pai et al. (2004) [5] revealed that the prevalence of Streptococcus spp. in the intestinal content and surface of American and German cockroaches were $38.10 \%$ and $38.80 \%$ and $32.80 \%$ and $17.20 \%$, respectively. Similar findings were achieved in the studies conducted in Iran [22, 23], Thailand [24] and Brazil [25].

Results of our investigation indicated that the Streptococcus spp. strains isolated from cockroaches harbored the high prevalence of resistance against commonly used antibiotic, particularly tetracycline, trimethoprim, enrofloxacin, erythromycin, lincomycin and penicillin. The findings demonstrate the antibiotic resistance seriousness of the common pathogenic bacteria in Iran. A boost prevalence of antibiotic resistance was also reported in the pathogenic bacteria in the hospitals of Taiwan [26]. More than $30 \%$ of S. pneumoniae, S. aureus, Enterobacteriaceae, $P$. aeruginosa, Acinetobacter baumannii, Haemophilus influenzae, coagulase-negative staphylococci, beta-hemolytic streptococci, viridans 
streptococci, and enterococcal isolates of Taiwanese hospitals were resistant to different antibiotics [26]. Pai et al. (2004) [5] reported that all of the species of common pathogenic bacteria (Streptococcus spp. $S$. aureus and $P$. aeruginosa) isolated from cockroaches harbored resistance against ampicillin, chloramphenicol, tetracycline, trimethoprim and sulfamethoxazole. Bouamama et al. (2010) [27] reported that pathogenic bacterial strains isolated from American cockroaches in Spain harbored the high prevalence of resistance against ampicillin, amoxicillin-clavulanate, cefoxitin; gentamicin, cotrimoxazole and ciprofloxacin antibiotics. Hammad and Mahdy (2012) [28] reported the high prevalence of antibiotic resistance of Streptococcus spp. isolated from cockroaches against ampicillin, cephalothin, chloramphenicol, ciprofloxacin, gentamycin, nalidixic acid, tetracycline, trimethoprim and sulfamethoxazole. Different patterns of antibiotic resistance of pathogenic bacterial strains isolated from cockroaches have been reported from Bangladesh [29], Nigeria [30], and India [31]. Such differences in the prevalence of antibiotic resistance reported in different study may be due to the differences in the idea of medical practitioners in antibiotic prescription, availability and expense of antibiotics and finally laws of various countries for antibiotic prescription. Furthermore, high prevalence of antibiotic resistance reported in the present study may be due to the irregular and unauthorized prescription of antibiotics. Phenotypic pattern of antibiotic resistance was supported by the genotypic profile of antibiotic resistance genes. We found that the genes encoding resistance against penicllins $(p b p)$, tetracyclines (tetK, tetM, tet $O$ and tetL), macrolides (erm and $m e f)$, streptogramins A and B ( $r p / V)$, and the lytA gene had considerable prevalence in the Streptococcus spp. strains isolated from hospital cockroaches. To the best of our knowledge, there existed no previously published data in this filed all around the world. High prevalence of $p b p$, tetK, tet $M$, tetO, tetL, erm, mef, rp/V and $/ y t A$ antibiotic resistance genes was reported in the Streptococcus spp. strains isolated from different hospital infections [32-34]. Kargar et al. (2012) [35] reported the high prevalence of ermB, mefA, $p b p 1 a, p b p 2 b$ and $p b p 2 x$ genes in the S. pneumonia strains isolated from different types of the hospital infections of hospitalized patients in Intensive Care Unit (ICU) centers. Presence of these genes in the Streptococcus spp. caused their severe resistance against some specific antibiotics. Our findings were also disclosed higher incidence of phenotypic profile of resistance to some antibiotic agents than genotypic profile. This finding is maybe owing to the fact that presence of antibiotic resistance genes is one of the known procedures for occurrence of antibiotic resistance in bacteria. In the other hand, higher incidence of phenotypic resistance toward antibiotics may support by procedures other than presence of antibiotic resistance genes.

The final part of the present research was focused on detecting putative virulence genes in the Streptococcus spp. strains isolated from different types of hospital cockroaches. We found that bac, cyl, $g I n A, c f b, h y l B, s c a A, b c a, s c p B$ and $I m b$ had considerable prevalence in the Streptococcus. Spp. strains isolated from hospital cockroaches. To the best of our knowledge, there existed no previously published data in this filed all around the world. The a-protein of protein $\mathrm{C}$ was encoded by bac and $b c a$ genes. This gene group helps bacteria to enter the host cells. Genes bac and bca were detected in $1.12 \%$ and $6.74 \%$ of bacteria, respectively. Eskandarian et al. (2015) [36] reported the bca and bac genes were found in $14.6 \%$ and $9.7 \%$ of Streptococcus isolates of hospital infections. Lower prevalence of the bac gene was reported from the United States, New Zealand and Europe [37-39]. We found that the prevalence of $c y l$, Imb, and 
$s c p B$ genes was $52.80 \%, 22.47 \%$ and $7.86 \%$, respectively. Duarte et al. (2005) [40] reported that the prevalence of $/ \mathrm{mb}$ and $s c p B$ genes in the Streptococcus spp. strains isolated from clinical samples was $97.30 \%$ and $96.70 \%$, respectively, which was higher than our findings. Franken et al. (2001) [41] and Dmitriev et al. (1999) [42] also reported higher prevalence of these genes. Cfb gene is encoded by complement factor $\mathrm{B}$ facilitating production of the essential component of the alternative course of complement activation. Factor B circulates in the blood as one chain polypeptide. This gene was also predominant in the Streptococcus spp. strains isolated from different hospital infections $[43,44]$.

Totally, the current survey revealed that hospital cockroaches, particularly oriental and American types, may be sources and reservoirs of pathogenic and antibiotic resistant Streptococcus spp. Thus, monitoring the presence of hospital cockroaches may be useful to decrease the dissemination of virulent and resistant bacteria in hospital environment.

\section{Conclusions}

In summary, results of the present study disclosed the high prevalence of different species of cockroaches in the hospital environment with high content of $S$. pyogenes, S. agalactiae and $S$. pneumoniae strains. High prevalence of resistance against the commonly used antibiotics with considerable distribution of virulence and antibiotic resistance genes in the Streptococcus spp. strains isolated from hospital cockroaches poses an important public health issue. Presence of multi-drug resistant strains increases the importance of the research. The present study shows the high importance of hospital cockroaches as dangerous reservoirs for harboring of virulent and resistant Streptococcus strains in the hospital environment and their transmission to human population. Moreover, with considerable rate of medically significant virulent and resistant bacteria, cockroaches may cause bacterial epidemic disease in hospitals. The findings indicate a possible role for cockroaches in the epidemiology of nosocomial infections, particularly those caused by Streptococcus spp. However, further studies are required to find additional knowledge about the microbiological and epidemiological roles of the hospital cockroaches in survival and transmission of virulent and antibiotic-resistant bacteria.

\section{Methods}

\section{Samples collection}

From July 2016 to July 2017, a total of 660 hospital cockroach samples were randomly collected from different educational hospitals (Chaharmahal Va Bakhtiari, Iran). The cockroaches were gathered using hand catch, sticky traps, and vacuum cleaners methods. For sampling, sterile hand-gloves were used. Separate clean and sterile plastic bags were utilized to transfer the collected cockroaches [45]. Only whole and alive cockroaches were investigated in the study. The samples were immediately transferred to Biotechnology Research Center, Shahrekord Branch, Sharekord, Iran. The cockroaches were identified using reliable taxonomic keys by an expert person in the Department of Entomology, Shahrekord University, Shahrekord, Iran [46]. 
Isolation and identification of Streptococcus spp.

Sterile normal saline (0.9\%) (5 mL) (Merck, Germany) was added to each test tube, and the cockroaches were vigorously washed and transferred to the secondary sterile test tubes using the sterile forceps. A loop full of each suspension was cultured on streptococcal selection broth (BD Biosciences, USA) and incubated at $37^{\circ} \mathrm{C}$ for $6 \mathrm{~h}$ with $5 \% \mathrm{CO}_{2}$. After enrichment, the samples were streaked onto $5 \%$ sheep blood agar and incubated at $37^{\circ} \mathrm{C}$ for $24-48 \mathrm{~h}$ with $5 \% \mathrm{CO}_{2}$. The suspected streptococcal colonies were purified on $\mathrm{BHI}$ agar (Merck, Germany).The cultures purified were tentatively identified on the basis of Gram's staining and biochemical tests, including bile esculin hydrolysis, catalase, and oxidase. Species identification was carried out using the certain biochemical tests, including hemolysis activity ( $S$. pneumonia (alpha), S. pyogenes (beta) and S. agalactiae (beta)), resistance to bacitracin (S. pneumonia (resistant/sensitive), S. pyogenes (sensitive) and S. agalactiae (resistant)), resistance to sulfamethoxazole (S. pneumonia (-), S. pyogenes (resistant) and S. agalactiae (resistant)), resistance to optochin (S. pneumonia (sensitive), S. pyogenes (resistant) and $S$. agalactiae (resistant)), bile:asculin activity (S. pneumonia (-/), S. pyogenes (-/) and S. agalactiae (-/+ and $/ /+))$ and growth on $6.5 \% \mathrm{NaCl}(S$. pneumonia (-), S. pyogenes (-) and $S$. agalactiae (-)). Confirmation of the species was carried out using the specific Polymerase Chain Reaction (PCR). Genomic DNA was extracted from bacterial colonies using the DNA extraction kit (Fermentas, Germany) according to the manufacturer's instruction. DNA quality and concentration were examined using the spectrophotometer. Table 1 shows the list of primers and the PCR conditions used to detect $S$. pyogenes, $S$. agalactiae and $S$. pneumonia in DNA samples. Primers specific for S. pyogenes, S. agalactiae and S. pneumonia were designed based on its conservative $16 \mathrm{~S}$ ribosomal RNA (16S rRNA) gene. Each PCR reaction contained $4 \mu \mathrm{L}$ of the extracted template DNA, 1.25U of Taq DNA polymerase, $1 \mu \mathrm{M}$ of each primer, $2 \mathrm{mM} \mathrm{MgCl} 2,5 \mu \mathrm{L}$ of $10 \mathrm{X}$ PCR buffer, $200 \mu \mathrm{M}$ dNTPs, and double-distilled water was added to a final volume of $25 \mu \mathrm{L}$.

\section{Antibiotic susceptibility test}

Antibiotic resistance patterns of Streptococcus spp. were specified by simple disk diffusion method. For antibiotic susceptibility test, the Mueller-Hinton agar (Merck, Germany) media were used. For this purpose, the principles proposed by the Clinical and Laboratory Standards Institute (CLSI) were used [47]. Susceptibility of Streptococcus spp. was tested against tetracycline (30 u/disk), penicillin (10 u/disk), cephalothin $(30 \mu \mathrm{g} /$ disk), gentamicin $(10 \mu \mathrm{g} /$ disk), ciprofloxacin $(5 \mu \mathrm{g} / \mathrm{disk})$, lincomycin (15 $\mu \mathrm{g} / \mathrm{disk})$, nitrofurantoin (300 $\mu \mathrm{g} /$ disk), enrofloxacin $(5 \mu \mathrm{g} /$ disk), sulfamethoxazole ( $25 \mu \mathrm{g} /$ disk), trimethoprim ( $5 \mu \mathrm{g} /$ disk), erythromycin ( $15 \mu \mathrm{g} /$ disk) and chloramphenicol ( $30 \mu \mathrm{g} /$ disk) antibiotic agents (Oxoid, UK). All of the inoculated plates were aerobically incubated at $37^{\circ} \mathrm{C}$ for $18-24 \mathrm{~h}$ in an aerobic atmosphere. Results were interpreted based on the instruction provided by CLSI (2015). S. pyogenes ATCC 12384, S. pneumonia ATCC 6305 and S. agalactiae ATCC 27956 were used as quality controls.

\section{PCR-based detection of virulence factors}

Table 1 represents the primer sequence and PCR conditions used to detect putative virulence factors in the Streptococcus spp. isolated from different types of hospital cockroaches. Each PCR reaction contained $5 \mu \mathrm{L}$ of 10X PCR amplification buffer, $2 \mu \mathrm{L}$ of extracted DNA, $1 \mathrm{U}$ of Taq DNA polymerase, $1 \mu \mathrm{M}$ 
of each primer, $2 \mathrm{mM} \mathrm{MgCl} 2,200 \mu \mathrm{M}$ dNTPs, and double-distilled water was added to a final volume of $25 \mu \mathrm{L}$.

PCR-based detection of antibiotic resistance genes

Table 1 represents the primer sequence and PCR conditions used to detect penicillin, macrolide, streptogramin and tetracycline antibiotic resistance genes in the Streptococcus spp. isolated from different types of hospital cockroaches. Each PCR reaction contained $3 \mu \mathrm{L}$ of extracted template DNA, $1 \mathrm{U}$ of Taq DNA polymerase, $1 \mu \mathrm{M}$ of each primer, $2 \mathrm{mM} \mathrm{MgCl} 2,5 \mu \mathrm{L}$ of $10 \mathrm{X}$ PCR buffer, $200 \mu \mathrm{M}$ dNTPs, and double-distilled water was added to a final volume of $25 \mu \mathrm{L}$.

Agarose gel electrophoresis

The PCR amplified products $(10 \mu \mathrm{L})$ were subjected to electrophoresis on a 1.5\% agarose gel in 1X TBE buffer at $80 \mathrm{~V}$ for 30-40 min stained with a solution of Ethidium Bromide (Fermentas, Germany) and examined under Ultra Violet illumination (Uvitec, UK).

Statistical analysis

The data obtained from all the tests were entered the Microsoft Excel spreadsheet (Microsoft Corp., Redmond, WA) to be analyzed. All the data were first presented to Kolmogorov-Smirnov test in order to study their distribution. In this respect, the statistical analysis was then conducted using SPSS/20.0 software (SPSS Inc., Chicago, IL). P-values were calculated using Chi-square and Fisher's exact tests to find any significant relationship for prevalence Streptococcus spp. and their virulence factors and antibiotic resistance properties among different types of hospital cockroaches. The p-value less than 0.05 was considered statistically significant.

\section{Abbreviations}

S. pneumoniae: Streptococcus pneumoniae S. pyogenes:Streptococcus pyogenes S. agalactiae: Streptococcus agalactiae bac: encode for $\beta$-antigen cyl: encode for $\beta$-hemolysin, glnA: encode for glutamine synthetase, $\mathbf{c f b}$ : encode for the Christie-Atkins-Munch-Peterson (CAMP) factor, hylB: encode for hyaluronidase, scaA: encode for aggregation factor, bca: encode for a-antigen scpB: C5a peptidase Imb laminin binding protein CLSI: Clinical Laboratory Standards Institute PCR: Polymerase chain reaction

\section{Declarations}

\section{- Ethics approval and consent to participate}

Ethical Committee of Research of the Baqiyatallah University of Medical Sciences, Tehran, Iran (Consent Ref Number 96-91002480). Verification of this research project and the licenses related to sampling process were approved by Prof. Reza Ranjbar (Approval Ref Number Med-96-91002480). 
- Consent to publish

Not Applicable

- Availability of data and materials

The datasets used and/or analyzed during the current study available from the corresponding author on reasonable request.

- Competing interests

The authors declare that they have no competing interests.

- Funding

The authors declare that no funding was received for the research.

\section{- Authors' Contributions}

R. R. and M.C. conceived and designed the study; M.C. conducted the research; M.C. performed the experiments. R. R. and M.C. Analyzed the data. M.C. carried out the writing and drafting of the manuscript. All authors read and approved the final manuscript.

- Acknowledgements

We would like to thank from the "Clinical Research Development Center of Baqiyatallah hospital" for their kindly cooperation. This study was financially supported in part by "Clinical Research Development Center of Baqiyatallah hospital. The authors also gratefully acknowledge all the staff of biotechnology research center, Shahrekord branch, Islamic Azad university, Shahrekord in southwest Iran for their sincere support.

\section{- Authors' Information}

1 Young Researchers and Elite Club, Shahrekord Branch, Islamic Azad University, Shahrekord, Iran. Mohammad Chehelgerdi

2 Molecular Biology Research Center, Systems Biology and Poisonings Institute, Baqiyatallah University of Medical Sciences, Tehran, Iran. Reza Ranjbar

\section{References}

1. Doosti A, Pourabbas M, Arshi A, Chehelgerdi M, Kabiri H. TEM and SHV Genes in Klebsiella pneumoniae Isolated from Cockroaches and Their Antimicrobial Resistance Pattern. Osong Public Heal Res Perspect. 2015;6:3-8. 
2. Pomés A, Arruda LK. Investigating cockroach allergens: Aiming to improve diagnosis and treatment of cockroach allergic patients. Methods. 2014;66:75-85.

3. Lemos AA, Lemos JA, Prado MA, Pimenta FC, Gir E, Silva HM, et al. Cockroaches as carriers of fungi of medical importance. Mycoses. 2006;49:23-5.

4. Tetteh-Quarcoo PB, Donkor ES, Attah SK, Duedu KO, Afutu E, Boamah I, et al. Microbial carriage of cockroaches at a tertiary care hospital in ghana. Environmental health insights. 2013;7 August 2015:59-66. doi:10.4137/EHI.S12820.

5. Pai H-H, Chen W-C, Peng C-F. Cockroaches as potential vectors of nosocomial infections. Infect Control Hosp Epidemiol. 2004;25:979-84. doi:10.1086/502330.

6. Fakoorziba MR, Eghbal F, Hassanzadeh J, Moemenbellah-Fard MD. Cockroaches ( Periplaneta americana and Blattella germanica) as potential vectors of the pathogenic bacteria found in nosocomial infections. Ann Trop Med Parasitol. 2010;104:521-8. doi:10.1179/136485910X12786389891326.

7. Stevens DL, Bryant AE. Severe Group A Streptococcal Infections. Streptococcus pyogenes Basic Biol to Clin Manifestations. 2016; Figure 1:1-22. http://www.ncbi.nlm.nih.gov/pubmed/26866227.

8. Tunkel AR, Sepkowitz KA. Infections Caused by Viridans Streptococci in Patients with Neutropenia. Clin Infect Dis. 2002;34:1524-9. doi:10.1086/340402.

9. Krzyaściak W, Pluskwa KK, Jurczak A, Koaścielniak D. The pathogenicity of the Streptococcus genus. European Journal of Clinical Microbiology and Infectious Diseases. 2013;32:1361-76.

10. Ruppen C, Notter J, Strahm C, Sonderegger B, Sendi P. Osteoarticular and skin and soft-tissue infections caused by Streptococcus agalactiae in elderly patients are frequently associated with bacteremia. Diagn Microbiol Infect Dis. 2018;90:55-7.

11. Edwards MS, Baker CJ. Group B streptococcal infections in elderly adults. Clin Infect Dis an Off Publ Infect Dis Soc Am. 2005;41:839-47. doi:10.1086/432804.

12. Musher DM. Infections Caused by Streptococcus pneumoniae: Clinical Spectrum, Pathogenesis, Immunity, and Treatment. Clin Infect Dis. 1992;14:801-9.

13. Cattoir V. Mechanisms of Antibiotic Resistance. 2016. http://www.ncbi.nlm.nih.gov/pubmed/26866217. Accessed 4 Feb 2018.

14. Lin K, Tierno Jr. PM, Komisar A. Increasing antibiotic resistance of streptococcus species in New York City. Laryngoscope. 2004;114:1147-50.

15. Sapkota AR, Ojo KK, Roberts MC, Schwab KJ. Antibiotic resistance genes in multidrug-resistant Enterococcus spp. and Streptococcus spp. recovered from the indoor air of a large-scale swinefeeding operation. Lett Appl Microbiol. 2006;43:534-40.

16. Kayansamruaj P, Pirarat N, Katagiri T, Hirono I, Rodkhum C. Molecular characterization and virulence gene profiling of pathogenic Streptococcus agalactiae populations from tilapia (Oreochromis sp.) farms in Thailand. J Vet Diagnostic Investig. 2014;26:488-95. 
17. Blumental S, Granger-Farbos A, Moïsi JC, Soullié B, Leroy P, Njanpop-Lafourcade BM, et al. Virulence factors of Streptococcus pneumoniae. Comparison between African and French invasive isolates and implication for future vaccines. PLoS One. 2015;10.

18. Fotedar R, Shriniwas UB, Verma A. Cockroaches (Blattella germanica) as carriers of microorganisms of medical importance in hospitals. Epidemiol Infect. 1991;107:181-7.

19. Kassiri H, Kassiri A, Kazemi S. Investigation on American cockroaches medically important bacteria in Khorramshahr hospital, Iran. Asian Pacific J Trop Dis. 2014;4:201-3.

20. Elgderi RM, Ghenghesh KS, Berbash N. Carriage by the German cockroach ( Blattella germanica) of multiple-antibiotic-resistant bacteria that are potentially pathogenic to humans, in hospitals and households in Tripoli, Libya. Ann Trop Med Parasitol. 2006;100:55-62. doi:10.1179/136485906X78463.

21. Salehzadeh A, Tavacol P, Mahjub H. Bacterial, fungal and parasitic contamination of cockroaches in public hospitals of Hamadan, Iran. J Vector Borne Dis. 2007;44:105-10.

22. Ahmad Vahhabi A, Shemshad K, Mohammadi P, Sayyadi M, Shemshad M, Rafinejad J. Microbiological study of domestic cockroaches in human dwelling localities. African J Microbiol Res. 2011;5:5790-2. doi:10.5897/AJMR11.1075.

23. Kassiri H, Shahnaz K. Cockroaches [periplaneta americana (L.), dictyoptera; blattidae] as carriers of bacterial pathogens, khorramshahr County, Iran. Jundishapur J Microbiol. 2012;5:320-2. http://www.sid.ir/En/Journal/ViewPaper.aspx?ID=261361. Accessed 5 Feb 2018.

24. Chaichanawongsaroj N, Vanichayatanarak K, Pipatkullachat T, Polrojpanya M, Somkiatcharoen S. Isolation of gram-negative bacteria from cockroaches trapped from urban environment. Southeast Asian J Trop Med Public Health. 2004;35:681-4.

25. Prado MA, Gir E, Pereira MS, Reis C, Preto R, Brazil S; , et al. Profile of Antimicrobial Resistance of Bacteria Isolated from Cockroaches (Periplaneta americana) in a Brazilian Health Care Institution. Brazilian J Infect Dis. 2006;10:26-32. www.bjid.com.br.

26. Chang SC, Hsieh WC, Liu CY. High prevalence of antibiotic resistance of common pathogenic bacteria in Taiwan. The Antibiotic Resistance Study Group of the Infectious Disease Society of the Republic of China. Diagn Microbiol Infect Dis. 2000;36:107-12.

http://www.ncbi.nlm.nih.gov/entrez/query.fcgi? $\mathrm{cmd}=$ Retrieve\&db=PubMed\&dopt=Citation\&list_uids $=10705052$.

27. Bouamama L, Sorlozano A, Laglaoui A, Lebbadi M, Aarab A, Gutierrez J. Antibiotic resistance patterns of bacterial strains isolated from Periplaneta americana and Musca domestica in Tangier, Morocco. J Infect Dev Ctries. 2010;4:194-201.

28. Hammad KM, Mahdy HM. Antibiotic resistant-bacteria associated with the cockroach, Periplaneta americana collected from different habitat in Egypt. New York Sci J N Y Sci J. 2012;55:198-206. http://www.sciencepub.net/newyork. Accessed 5 Feb 2018.

29. Islam A, Aurjun ND, Islam K, Islam S, Chakma S, Muhammad BH, et al. Isolation, identification and antimicrobial resistance profile of Staphylococcus aureus in Cockroaches (Periplaneta a mericana ). 
Vet Anim Res J Adv Vet Anim Res Islam al J Adv Vet Anim Res. 2016;3:221-8. doi:10.5455/javar.2016.c153.

30. Atreyi Chakraborty, Nishith K. Pal, Soma Sarkar, Manideepa Sen Gupta. Antimicrobial resistance pattern of Enterococcus spp. isolated from Cockroaches from Ekiti State Teaching Hospital. http://ijbst.com/issue/Oct-Dec-2015/Antimicrobial-resistance-pattern-of-Enterococcus-spp.-isolatedfrom-Cockroaches-from-Ekiti-State-Teaching-Hospital/. Accessed 7 Feb 2018.

31. Leshan Wannigama D, Dwivedi R, Zahraei-Ramazani A. Prevalence and antibiotic resistance of gramnegative pathogenic bacteria species isolated from periplaneta americana and blattella germanica in Varanasi, India. J Arthropod Borne Dis. 2013;8:10-20.

32. Malhotra-Kumar S, Lammens C, Piessens J, Goossens H. Multiplex PCR for simultaneous detection of macrolide and tetracycline resistance determinants in streptococci. Antimicrob Agents Chemother. 2005;49:4798-800.

33. Zeng X, Kong F, Wang H, Darbar A, Gilbert GL. Simultaneous detection of nine antibiotic resistancerelated genes in Streptococcus agalactiae using multiplex PCR and reverse line blot hybridization assay. Antimicrob Agents Chemother. 2006;50:204-9.

34. Xu X, Cai L, Xiao M, Kong F, Oftadeh S, Zhou F, et al. Distribution of serotypes, genotypes, and resistance determinants among macrolide-resistant Streptococcus pneumoniae isolates. Antimicrob Agents Chemother. 2010;54:1152-9.

35. M. K, M. B, S. G-D. Multi-drug resistance and molecular pattern of erythromycin and penicillin resistance genes in Streptococcus pneumoniae. African J Biotechnol. 2012;11 4 PG-968-973:96873. doi:http://dx.doi.org/10.5897/AJB11.2783.

36. Eskandarian N, Ismail Z, Neela V, van Belkum A, Desa MNM, Amin Nordin S. Antimicrobial susceptibility profiles, serotype distribution and virulence determinants among invasive, non-invasive and colonizing Streptococcus agalactiae (group B streptococcus) from Malaysian patients. Eur J Clin Microbiol Infect Dis. 2015;34:579-84.

37. Persson E, Berg S, Bevanger L, Bergh K, Valsö-Lyng R, Trollfors B. Characterisation of invasive group B streptococci based on investigation of surface proteins and genes encoding surface proteins. Clin Microbiol Infect. 2008;14:66-73.

38. Manning SD, Ki M, Marrs CF, Kugeler KJ, Borchardt SM, Baker CJ, et al. The frequency of genes encoding three putative group B streptococcal virulence factors among invasive and colonizing isolates. BMC Infect Dis. 2006;6.

39. Sadowy E, Matynia B, Hryniewicz W. Population structure, virulence factors and resistance determinants of invasive, non-invasive and colonizing Streptococcus agalactiae in Poland. J Antimicrob Chemother. 2010;65:1907-14.

40. Duarte RS, Bellei BC, Miranda OP, Brito MAVP, Teixeira LM. Distribution of antimicrobial resistance and virulence-related genes among Brazilian group B streptococci recovered from bovine and human sources. Antimicrob Agents Chemother. 2005;49:97-103. 
41. Franken C, Haase G, Brandt C, Weber-Heynemann J, Martin S, Lämmler C, et al. Horizontal gene transfer and host specificity of beta-haemolytic streptococci: The role of a putative composite transposon containing scpB and Imb. Mol Microbiol. 2001;41:925-35.

42. Dmitriev a, Tkáciková L, Suvorov a, Kantíková M, Mikula I, Totolyan a. Comparative genetic study of group B streptococcal strains of human and bovine origin. Folia Microbiol (Praha). 1999;44:449-53. http://www.ncbi.nlm.nih.gov/pubmed/10983241.

43. Udo EE, Boswihi SS, Al-Sweih N. Genotypes and virulence genes in group B streptococcus isolated in the maternity hospital, Kuwait. Med Princ Pract. 2013;22:453-7.

44. Ding Y, Zhao J, He X, Li M, Guan H, Zhang Z, et al. Antimicrobial resistance and virulence-related genes of Streptococcus obtained from dairy cows with mastitis in Inner Mongolia, China. Pharm Biol. 2016;54:162-7. doi:10.3109/13880209.2015.1025290.

45. Paul S, Khan AM, Baqui MA, Muhibullah M. Evaluation of the common cockroach Periplaneta americana (L.) as carrier of medically important bacteria. J Commun Dis. 1992;24:206-10.

46. Burgess NRH. Cockroaches (Blattaria). In: Medical Insects and Arachnids. Dordrecht: Springer Netherlands; 1993. p. 473-82. doi:10.1007/978-94-011-1554-4_13.

47. Wayne P. Performance Standards for Antimicrobial Susceptibility Testing; Twenty-Fifth Informational Supplement M100 - S25. 2015.

\section{Tables}

Table 1. Oligonucleotide primers and PCR conditions used to detect Streptococcus spp., virulence factors and antibiotic resistance genes. 


\begin{tabular}{|c|c|c|c|}
\hline Gene & Primer sequence $\left(5^{\prime}-3^{\prime}\right)$ & $\begin{array}{l}\text { Amplicon } \\
\text { size (bp) }\end{array}$ & PCR program \\
\hline $\begin{array}{c}\text { S. } \\
\text { pyogenes }\end{array}$ & $\begin{array}{c}\text { GGTTTGATGGGGATAAGGTGC } \\
\text { TGGAAGTTAAAGTGAGTTGTCTGC }\end{array}$ & 370 & $\begin{array}{c}1 \text { cycle: } 94 \text { 0C / } 8 \text { min. } 32 \text { cycle: } 95 \text { 0C / } 61 \text { s } 55 \text { 0C / } 70 \text { s } 72 \text { 0C / } 2 \\
\text { min } 1 \text { cycle: } 72 \text { 0C / } 8 \text { min }\end{array}$ \\
\hline $\begin{array}{c}\text { S. } \\
\text { pneumonia }\end{array}$ & $\begin{array}{l}\text { CTGTTACTTGTTCTGGACTCTCGATAATTGG } \\
\text { GCССАСTССТGTTAAAATCCTACССGСАTTG }\end{array}$ & 430 & $\begin{array}{c}1 \text { cycle: } 94 \text { 0C / } 8 \text { min. } 32 \text { cycle: } 95 \text { 0C / } 65 \text { s } 55 \text { 0C / } 70 \text { s } 72 \text { 0C / } 2 \\
\text { min } 1 \text { cycle: } 72 \text { 0C / } 8 \text { min } 72 \text { 0C / } 5 \mathrm{~min}\end{array}$ \\
\hline $\begin{array}{l}S . \\
\text { agalactiae }\end{array}$ & $\begin{array}{l}\text { TAGATGGCGAATTCACTGAGA } \\
\text { ATTGAGCAATCCCTATCACG }\end{array}$ & 112 & $\begin{array}{c}1 \text { cycle: } 94 \text { 0C / } 8 \text { min. } 32 \text { cycle: } 95 \text { 0C / } 60 \text { s } 60 \text { 0C / } 70 \text { s } 72 \text { 0C / } 2 \\
\text { min } 1 \text { cycle: } 72 \text { 0C / } 8 \text { min }\end{array}$ \\
\hline LytA & $\begin{array}{l}\text { CAACCGTACAGAATGAAGCGG } \\
\text { TTATTCGTGCAATACTCGTGCG }\end{array}$ & 319 & $\begin{array}{c}1 \text { cycle: } 94 \text { 0C / } 8 \text { min. } 32 \text { cycle: } 95 \text { 0C / } 62 \text { s } 55 \text { 0C / } 70 \text { s } 72 \text { 0C / } 2 \\
\text { min } 1 \text { cycle: } 72 \text { oC / } 8 \text { min } 72 \text { oC / } 5 \text { min }\end{array}$ \\
\hline pbp1a & $\begin{array}{l}\text { AAACAAGGTCGGACTCAACC } \\
\text { ATATACATTGGTTTATAGTAAGTT }\end{array}$ & 195 & $\begin{array}{c}1 \text { cycle: } 94 \text { 0C / } 8 \text { min. } 32 \text { cycle: } 95 \text { 0C / } 60 \text { s } 55 \text { 0C / } 70 \text { s } 72 \text { 0C / } 2 \\
\text { min } 1 \text { cycle: } 72 \text { 0C / } 8 \text { min }\end{array}$ \\
\hline $\operatorname{pbp} 2 x$ & $\begin{array}{l}\text { CCAGGTTCCACTATGAAAGTG } \\
\text { ATCCCAACGTTACTTGAGTGT }\end{array}$ & 203 & $\begin{array}{c}1 \text { cycle: } 94 \text { 0C / } 8 \text { min. } 32 \text { cycle: } 95 \text { 0C / } 61 \text { s } 57 \text { 0C / } 70 \text { s } 72 \text { 0C / } 2 \\
\text { min } 1 \text { cycle: } 72 \text { 0C / } 8 \text { min }\end{array}$ \\
\hline pbp2b & $\begin{array}{l}\text { CCTATATGGTCCAAACAGCCT } \\
\text { GGTCAATTCCTGTCGCAGTA }\end{array}$ & 147 & $\begin{array}{c}1 \text { cycle: } 94 \text { 0C / } 8 \text { min. } 32 \text { cycle: } 95 \text { 0C / } 60 \text { s } 58 \text { 0C / } 70 \text { s } 72 \text { 0C / } 2 \\
\text { min } 1 \text { cycle: } 72 \text { oC / } 8 \text { min } 72 \text { 0C / } 5 \text { min }\end{array}$ \\
\hline mefA & $\begin{array}{l}\text { CTGTATGGAGCTACCTGTCTGG } \\
\text { CCCAGCTTAGGTATACGTAC }\end{array}$ & 294 & $\begin{array}{c}1 \text { cycle: } 94 \text { 0C / } 8 \text { min. } 32 \text { cycle: } 95 \text { 0C / } 60 \text { s } 58 \text { 0C / } 70 \text { s } 72 \text { 0C / } 2 \\
\text { min } 1 \text { cycle: } 72 \text { oC / } 8 \text { min } 72 \text { 0C / } 5 \text { min }\end{array}$ \\
\hline ermB & $\begin{array}{l}\text { CGTACCTTGGATATTCACCG } \\
\text { GTAAACAGTTGACGATATTCTCG }\end{array}$ & 224 & $\begin{array}{l}1 \text { cycle: } 94 \text { 0C / } 8 \text { min. } 32 \text { cycle: } 95 \text { 0C / } 61 \text { s } 57 \text { 0C / } 70 \text { s } 72 \text { 0C / } 2 \\
\qquad \min 1 \text { cycle: } 72 \text { 0C / } 8 \text { min }\end{array}$ \\
\hline DF-L22 & $\begin{array}{l}\text { GAACTCAGCTGTAGCTAACGC } \\
\text { TTCTGCAACAGCTACAGTGATG }\end{array}$ & 176 & $\begin{array}{c}1 \text { cycle: } 94 \text { 0C / } 8 \text { min. } 32 \text { cycle: } 95 \text { 0C / } 60 \text { s } 57 \text { 0C / } 70 \text { s } 72 \text { 0C / } 2 \\
\text { min } 1 \text { cycle: } 72 \text { oC / } 8 \text { min } 72 \text { 0C / } 5 \text { min }\end{array}$ \\
\hline DF-L4 & $\begin{array}{l}\text { AGCGATGCAGTATTTGGTATCG } \\
\text { GCCGTATGAACGTGGAGTTG }\end{array}$ & 236 & $\begin{array}{c}1 \text { cycle: } 94 \text { 0C / } 8 \text { min. } 32 \text { cycle: } 95 \text { 0C / } 60 \text { s } 58 \text { 0C / } 70 \text { s } 72 \text { 0C / } 2 \\
\text { min } 1 \text { cycle: } 72 \text { 0C / } 8 \text { min } 72 \text { 0C / } 5 \mathrm{~min}\end{array}$ \\
\hline
\end{tabular}




\begin{tabular}{|c|c|c|c|}
\hline tetM & $\begin{array}{l}\text { GAACTCGAACAAGAGGAAAGC } \\
\text { ATGGAAGCCCAGAAAGGAT }\end{array}$ & 740 & $\begin{array}{c}1 \text { cycle: } 94 \text { 0C / } 8 \text { min. } 32 \text { cycle: } 95 \text { 0C / } 60 \text { s } 55 \text { 0C / } 70 \text { s } 72 \text { 0C / } 2 \\
\text { min } 1 \text { cycle: } 72 \text { 0C / } 8 \text { min } 72 \text { 0C / } 5 \text { min }\end{array}$ \\
\hline tetO & $\begin{array}{l}\text { AACTTAGGCATTCTGGCTCAC } \\
\text { TCCCACTGTTCCATATCGTCA }\end{array}$ & 519 & $\begin{array}{c}1 \text { cycle: } 94 \text { 0C / } 8 \text { min. } 32 \text { cycle: } 95 \text { 0C / } 60 \text { s 520C / } 70 \text { s } 72 \text { 0C / } 2 \\
\text { min } 1 \text { cycle: } 72 \text { 0C / } 8 \text { min } 72 \text { 0C/ } 5 \text { min }\end{array}$ \\
\hline tetL & $\begin{array}{l}\text { TGAACGTCTCATTACCTG } \\
\text { ACGAAAGCCCACCTAAAA }\end{array}$ & 993 & $\begin{array}{c}1 \text { cycle: } 94 \text { 0C / } 8 \text { min. } 32 \text { cycle: } 95 \text { 0C / } 61 \text { s 500C / } 70 \text { s } 72 \text { 0C / } 2 \\
\text { min } 1 \text { cycle: } 72 \text { 0C / } 8 \text { min }\end{array}$ \\
\hline tetK & $\begin{array}{l}\text { TCCTGGAACCATGAGTGT } \\
\text { AGATAATCCGCCCATAAC }\end{array}$ & 189 & $\begin{array}{c}1 \text { cycle: } 94 \text { 0C / } 8 \text { min. } 32 \text { cycle: } 95 \text { 0C / } 60 \text { s } 50 \text { 0C / } 70 \text { s } 72 \text { 0C / } 2 \\
\text { min } 1 \text { cycle: } 72 \text { 0C / } 8 \text { min } 72 \text { 0C / } 5 \text { min }\end{array}$ \\
\hline $\mathrm{Bac}$ & $\begin{array}{l}\text { TGTAAAGGACGATAGTGTGAAGAC } \\
\text { CATTTGTGATTCCCTTTTGC }\end{array}$ & 530 & $\begin{array}{c}1 \text { cycle: } 94 \text { 0C / } 8 \text { min. } 32 \text { cycle: } 95 \text { 0C / } 60 \text { s } 50 \text { 0C / } 70 \text { s } 72 \text { 0C / } 2 \\
\text { min } 1 \text { cycle: } 72 \text { 0C / } 8 \text { min } 72 \text { 0C / } 5 \mathrm{~min}\end{array}$ \\
\hline Bca & $\begin{array}{l}\text { TAACAGTTATGATACTTCACAGAC } \\
\text { ACGACTTTCTTCCGTCCACTTAGG }\end{array}$ & 535 & $\begin{array}{c}1 \text { cycle: } 94 \text { 0C / } 8 \text { min. } 32 \text { cycle: } 95 \text { 0C / } 60 \text { s } 51 \text { 0C / } 70 \text { s } 72 \text { 0C / } 2 \\
\text { min } 1 \text { cycle: } 72 \text { oC / } 8 \text { min } 72 \text { 0C / } 5 \text { min }\end{array}$ \\
\hline ScpB & $\begin{array}{l}\text { CCAAGACTTCAGCCACAAGG } \\
\text { CAATTCCAGCCAATAGCAGC }\end{array}$ & 591 & $\begin{array}{c}1 \text { cycle: } 94 \text { 0C / } 8 \text { min. } 32 \text { cycle: } 95 \text { 0C / } 60 \text { s } 57 \text { OC / } 70 \text { s } 72 \text { 0C / } 2 \\
\text { min } 1 \text { cycle: } 72 \text { 0C / } 8 \text { min } 72 \text { 0C / } 5 \text { min }\end{array}$ \\
\hline Lmb & $\begin{array}{l}\text { ACCGTCTGAAATGATGTGG } \\
\text { GATTGACGTTGTCTTCTGC }\end{array}$ & 572 & $\begin{array}{l}1 \text { cycle: } 94 \text { 0C / } 8 \text { min. } 32 \text { cycle: } 95 \text { 0C / } 61 \text { s } 51 \text { 0C / } 70 \text { s } 72 \text { 0C / } 2 \\
\text { min } 1 \text { cycle: } 72 \text { 0C / } 8 \mathrm{~min}\end{array}$ \\
\hline Cyl & $\begin{array}{l}\text { ACGGCTTGTCCATAGTAGTGTTTG } \\
\text { AACGACACTGCCATCAGCAC }\end{array}$ & 345 & $\begin{array}{c}1 \text { cycle: } 94 \text { 0C / } 8 \text { min. } 32 \text { cycle: } 95 \text { 0C / } 60 \text { s } 52 \text { 0C / } 70 \text { s } 72 \text { 0C / } 2 \\
\text { min } 1 \text { cycle: } 72 \text { 0C / } 8 \text { min } 72 \text { 0C / } 5 \text { min }\end{array}$ \\
\hline $\mathrm{Gln} A$ & $\begin{array}{l}\text { ACGTATGAACAGAGTTGGCTATAA } \\
\text { TCCTCTGATAATTGCATTCCAC }\end{array}$ & 471 & $\begin{array}{c}1 \text { cycle: } 94 \text { 0C / } 8 \text { min. } 32 \text { cycle: } 95 \text { 0C / } 60 \text { s } 52 \text { 0C / } 70 \text { s } 72 \text { 0C / } 2 \\
\text { min } 1 \text { cycle: } 72 \text { 0C / } 8 \text { min } 72 \text { 0C / } 5 \text { min }\end{array}$ \\
\hline ScaA & $\begin{array}{l}\text { ACGGTATCAACCTTGAAACTGG } \\
\text { TCAGTGTTGATTTCCCAGATGTA }\end{array}$ & 256 & $\begin{array}{c}1 \text { cycle: } 94 \text { 0C / } 8 \text { min. } 32 \text { cycle: } 95 \text { 0C / } 60 \text { s } 52 \text { 0C / } 70 \text { s } 72 \text { 0C / } 2 \\
\text { min } 1 \text { cycle: } 72 \text { 0C / } 8 \text { min } 72 \text { 0C / } 5 \text { min }\end{array}$ \\
\hline HylB & $\begin{array}{l}\text { ACAAATGGAACGACGTGACTAT } \\
\text { CACCAATTGGCAGAGCCT }\end{array}$ & 346 & $\begin{array}{c}1 \text { cycle: } 94 \text { 0C / } 8 \text { min. } 32 \text { cycle: } 95 \text { 0C / } 60 \text { s } 52 \text { 0C / } 70 \text { s } 72 \text { 0C / } 2 \\
\text { min } 1 \text { cycle: } 72 \text { oC / } 8 \text { min } 72 \text { 0C / } 5 \text { min }\end{array}$ \\
\hline
\end{tabular}


Table 2: Total distribution of Streptococcus spp. isolated from different types of hospital cockroaches.

\begin{tabular}{|c|c|c|c|c|}
\hline \multirow{2}{*}{ Samples } & \multirow{2}{*}{ No. samples } & \multicolumn{3}{|c|}{ Prevalence of Streptococcus spp. (\%) } \\
\cline { 3 - 5 } & & S. pyogenes & S. agalactiae & S. pneumonia \\
\hline German cockroaches & 161 & $8(4.96)$ & $1(0.62)$ & $11(6.83)$ \\
\hline American cockroaches & 285 & $11(3.85)$ & $5(1.75)$ & $22(7.71)$ \\
\hline Oriental cockroaches & 140 & $8(5.71)$ & $4(2.85)$ & $6(4.28)$ \\
\hline Other species & 74 & $5(6.75)$ & $1(1.35)$ & $7(9.45)$ \\
\hline Total & 660 & $32(4.84)$ & $11(1.66)$ & $46(6.96)$ \\
\hline
\end{tabular}

Table 3. Distribution of streptococcal putative virulence factors of in different types of the studied cockroaches. 


\begin{tabular}{|c|c|c|c|c|c|}
\hline \multirow[t]{2}{*}{ Virulence factors } & \multicolumn{5}{|c|}{ Cockroaches species (n) } \\
\hline & German $(n=20)$ & American $(n=38)$ & Oriental $(n=18)$ & Other species $(n=13)$ & Total number $(n=89)$ \\
\hline$B c a$ & 2 & 2 & 1 & 1 & 6 \\
\hline$B a c$ & 1 & 0 & 0 & 0 & 1 \\
\hline$S c p B$ & 2 & 2 & 1 & 2 & 7 \\
\hline$L m b$ & 6 & 9 & 3 & 2 & 20 \\
\hline Cyl & 14 & 19 & 8 & 6 & 47 \\
\hline$G \ln A$ & 15 & 20 & 6 & 4 & 45 \\
\hline$C f b$ & 17 & 22 & 9 & 0 & 48 \\
\hline HylB & 11 & 17 & 6 & 5 & 39 \\
\hline$S c a A$ & 15 & 24 & 6 & 1 & 46 \\
\hline
\end{tabular}

Table 4. Distribution of penicillin, macrolides, tetracyclines and streptogramins antibiotic resistance genes among the Streptococcus spp. isolated from different types of hospital cockroaches. 


\begin{tabular}{|c|c|c|c|c|c|}
\hline \multirow[t]{2}{*}{ Resistance genes } & \multicolumn{5}{|c|}{ Cockroaches species (n) } \\
\hline & German $(n=20)$ & American $(n=38)$ & Oriental $(n=18)$ & Other species $(n=13)$ & Total number $(\mathrm{n}=89)$ \\
\hline LytA & 4 & 17 & 3 & 1 & 25 \\
\hline pbp1a & 10 & 21 & 5 & 4 & 40 \\
\hline$p b p 2 x$ & 15 & 26 & 3 & 8 & 52 \\
\hline$p b p 2 b$ & 16 & 26 & 12 & 10 & 64 \\
\hline mefA & 12 & 22 & 1 & 6 & 41 \\
\hline ermB & 13 & 20 & 7 & 1 & 41 \\
\hline$D F-L 22$ & 6 & 8 & 5 & 0 & 19 \\
\hline$D F-L 4$ & 8 & 13 & 1 & 0 & 22 \\
\hline tetM & 6 & 17 & 14 & 4 & 41 \\
\hline teto & 3 & 2 & 0 & 1 & 6 \\
\hline tetL & 5 & 17 & 1 & 1 & 24 \\
\hline tetK & 15 & 23 & 1 & 1 & 40 \\
\hline
\end{tabular}

Table 5. Antibiotic resistance pattern of Streptococcus spp. isolated from different types of hospital cockroaches. 


\begin{tabular}{|c|c|c|c|c|c|c|c|c|c|c|c|c|}
\hline \multirow{2}{*}{$\begin{array}{c}\text { Bacteria (No. } \\
\text { positive) }\end{array}$} & \multicolumn{12}{|c|}{ Resistance to antimicrobial agent (\%) } \\
\hline & $\mathrm{P}^{*}$ & TET & LIN & ERY & ENR & CIP & W & SXT & $\mathrm{CEF}$ & CHL & NIT & GEN \\
\hline S. pyogenes(32) & $\begin{array}{c}26 \\
(81.25)\end{array}$ & $\begin{array}{c}27 \\
(84.37)\end{array}$ & $\begin{array}{c}9 \\
(28.12)\end{array}$ & $\begin{array}{c}17 \\
(53.12)\end{array}$ & $\begin{array}{c}18 \\
(56.25)\end{array}$ & $\begin{array}{c}7 \\
(21.87)\end{array}$ & $16(50)$ & $16(50)$ & $\begin{array}{c}13 \\
(40.62)\end{array}$ & $\begin{array}{c}2 \\
(6.25)\end{array}$ & - & $\begin{array}{c}14 \\
(43.75)\end{array}$ \\
\hline S. agalactiae(11) & $\begin{array}{c}7 \\
(63.63)\end{array}$ & $\begin{array}{c}8 \\
(72.72)\end{array}$ & $\begin{array}{c}6 \\
(54.54)\end{array}$ & $\begin{array}{c}7 \\
(63.63)\end{array}$ & $\begin{array}{c}5 \\
(45.45)\end{array}$ & $1(9.09)$ & $\begin{array}{c}8 \\
(72.72)\end{array}$ & $\begin{array}{c}4 \\
(36.36)\end{array}$ & $\begin{array}{c}4 \\
(36.36)\end{array}$ & $\begin{array}{c}1 \\
(9.09)\end{array}$ & - & $\begin{array}{c}2 \\
(18.18)\end{array}$ \\
\hline S. pneumonia(46) & $\begin{array}{c}17 \\
(36.95)\end{array}$ & $\begin{array}{c}37 \\
(80.43)\end{array}$ & $23(50)$ & $\begin{array}{c}17 \\
(36.95)\end{array}$ & $\begin{array}{c}13 \\
(28.26)\end{array}$ & $\begin{array}{c}9 \\
(19.56)\end{array}$ & $\begin{array}{c}34 \\
(73.91)\end{array}$ & $\begin{array}{c}11 \\
(23.91)\end{array}$ & $\begin{array}{c}13 \\
(28.26)\end{array}$ & - & - & $\begin{array}{c}10 \\
(21.73)\end{array}$ \\
\hline Total (89) & $\begin{array}{c}50 \\
(56.17)\end{array}$ & $\begin{array}{c}72 \\
(80.89)\end{array}$ & $\begin{array}{c}38 \\
(42.69)\end{array}$ & $\begin{array}{c}41 \\
(46.06)\end{array}$ & $\begin{array}{c}36 \\
(40.44)\end{array}$ & $\begin{array}{c}17 \\
(19.10)\end{array}$ & $\begin{array}{c}58 \\
(65.16)\end{array}$ & $\begin{array}{c}31 \\
(34.83)\end{array}$ & $\begin{array}{c}30 \\
(33.70)\end{array}$ & $\begin{array}{c}3 \\
(3.37)\end{array}$ & - & $\begin{array}{c}26 \\
(29.21)\end{array}$ \\
\hline
\end{tabular}

${ }^{*}$ P: Penicillin, TET: Tetracycline, LIN: Lincomycin, W: Trimethoprim, SXT: Sulfamethoxazole, ERY: Erythromycin, ENR: Enrofloxacin, CIP: Ciprofloxacin, CEF: Cefalotina, CHL: Chloramphenicol, GEN: Gentamicin, NIT: Nitrofurantoin. 